\title{
Evaluation of Landscape Change by Different Social Groups
}

Author(s): Marcel Hunziker, Patricia Felber, Katrin Gehring, Matthias Buchecker, Nicole Bauer, and Felix Kienast

Source: Mountain Research and Development, 28(2):140-147.

Published By: International Mountain Society

DOI: http://dx.doi.org/10.1659/mrd.0952

URL: http://www.bioone.org/doi/full/10.1659/mrd.0952

BioOne (www.bioone.org) is a nonprofit, online aggregation of core research in the biological, ecological, and environmental sciences. BioOne provides a sustainable online platform for over 170 journals and books published by nonprofit societies, associations, museums, institutions, and presses.

Your use of this PDF, the BioOne Web site, and all posted and associated content indicates your acceptance of BioOne's Terms of Use, available at www.bioone.org/page/terms_of_use.

Usage of BioOne content is strictly limited to personal, educational, and non-commercial use. Commercial inquiries or rights and permissions requests should be directed to the individual publisher as copyright holder. 


\section{Evaluation of Landscape Change by Different Social Groups Results of Two Empirical Studies in Switzerland}

Landscape is an important resource for mountain regions, particularly for tourism. Guiding future landscape development is necessary to meet the expectations of mountain inhabitants, tourists, and the general public outside mountain areas. The studies presented here show how different societal groups perceive past and future landscape changes in the Alps. The results reveal that it is not landscape change per se that is assessed as good or bad, it is the (related) change in the meaning of the landscape elements that leads to positive or negative assessments. There is a surprisingly broad consensus among different social groups regarding major landscape developments. However, there are also significant and relevant differences between these groups, eg between people living inside and outside the Alps, and between lay people and experts. Both conflicting and compatible views about landscape change are key elements in landscape planning.

Keywords: Landscape preferences; landscape history; social science; survey; qualitative interviews; group differences; experts vs lay people; Alps.

Peer-reviewed: December 2007 Accepted: January 2008

\section{Introduction and objectives}

In the past, (mountain) landscapes were produced and reproduced by the local population in their daily struggle for survival (Bätzing 1991). Landscape development was therefore merely an unconscious 'side-effect.' In the last few decades, however, mountain landscape development has been increasingly influenced by external forces (eg the global market, political strategies, external tourist demand, etc), at least in the Swiss Alps. Consequently, it has increasingly become a consciously perceived phenomenon, a planning issue, and therefore a task involving landscape-steering strategies for experts.

Due to the great value of landscapes as an important resource in Swiss mountain regions, particularly in relation to tourism (eg Messerli 1989; Lehmann et al 2007), and taking into account present and future economic and political developments and constraints (eg decreasing subsidies for agriculture), society must be involved in guiding landscape development. Planners need to know which specific landscape development is the most favorable in terms of ecology, economy, and society. With reference to ecology, climate change, and natural hazards, intense efforts have been made to provide the corresponding scientific basis, eg by the Man and Biosphere (MAB) National Research Program (NRP55) in the 1980s and the NRP31 in the 1990s (Lehmann et al 2007). Regarding societal preferences, however, the knowledge base is not yet as elaborated as in other fields. In particular, knowledge about perception and assessment of landscape changes among different societal groups has been missing. Such knowledge, however, is crucial for all landscape-related policies and planning measures, because it helps to identify planning goals that reconcile the views of various public groups and minimize conflicts.

The first objective of the studies presented here, therefore, was to investigate perception and judgment of (past) landscape changes, including perception of the rate of change. This knowledge is an important prerequisite to check the adaptive capacity of the population to landscape change. A second objective was to find divergent and convergent assessments among societal groups regarding future landscape changes (eg mountain and non-mountain populations, decision-makers and experts). These insights are important for steering landscape development in a stakeholder-related sense and for recognizing and reducing conflicts of interest.

\section{State of research and relevant research gaps}

The state of research on landscape preferences is reviewed in several articles. According to Zube (1984) the literature can be divided into "expert," "behavioral," and "humanistic" approaches, a classification that is often referred to (eg by Real et al 2000). Bourassa (1991) integrates existing literature on landscape aesthetics into a comprehensive paradigm, proposing 3 modes of aesthetic experience: biological, cultural, and personal. Aoki (1999) compiles literature from the 1960 s to 1990 s with a focus on methodological aspects. Hunziker et al (2007) provide the most recent overview of research on landscape preferences and related theories, and Backhaus et al (2007) synthesize the results of a recently concluded Swiss research program focusing, among other things, on landscape perception.

Specific results on differences between social groups regarding landscape preferences have been published by Yu (1995), Van den Berg et al (1998), Stamps (1999), Kaltenborn and Bjerke (2002), and Van den Berg and Koole (2006). Of particular interest are the articles by Stamps (1999), who conducted a meta-analysis of socio-demographic differences in landscape preferences, and by Van den Berg and Koole (2006), who focus on landscape developments such as rewildingalso an issue in the Swiss Alps.

Most of the above-mentioned landscape preference studies focus on assessing the aesthetic properties of landscapes at one single time. There is, however, a growing body of landscape historical studies concentrating on the attitudes of people towards historic landscape transformations (eg Russell 1997; Kienast et al 2007). This landscape historical aspect is important when it comes to 
TABLE 1 Descriptive summaries of the interviewees of the inductive part of this study.

\begin{tabular}{|c|c|c|c|c|c|c|}
\hline $\begin{array}{l}\text { Type of } \\
\text { community }\end{array}$ & $\begin{array}{l}\text { Number of } \\
\text { interviewees }\end{array}$ & Relationship with community & Years of birth & $\begin{array}{l}\text { Politically } \\
\text { active or not }\end{array}$ & Gender & Profession \\
\hline $\begin{array}{l}\text { Agrarian village } \\
\text { with some } \\
\text { influence from } \\
\text { tourism }\end{array}$ & 8 & $\begin{array}{l}\text { Long-term residents: } 4 \\
\text { New residents: } 2 \\
\text { Moved out: } 2\end{array}$ & $\begin{array}{l}\text { 1920s: } 4 \\
\text { 1940s: } 2 \\
\text { 1960s: } 2\end{array}$ & $\begin{array}{l}\text { Active: } 4 \\
\text { Not active: } 4\end{array}$ & $\begin{array}{l}\text { Female: } 4 \\
\text { Male: } 4\end{array}$ & $\begin{array}{l}\text { Farming: } 2 \\
\text { Business: } 2 \\
\text { Tourism: } 3 \\
\text { Education: } 1\end{array}$ \\
\hline Tourism village & 10 & $\begin{array}{l}\text { Long-term residents: } 5 \\
\text { New residents: } 2 \\
\text { Moved out: } 3\end{array}$ & $\begin{array}{l}\text { 1920s: } 4 \\
\text { 1940s: } 3 \\
\text { 1960s: } 3\end{array}$ & $\begin{array}{l}\text { Active: } 4 \\
\text { Not active: } 6\end{array}$ & $\begin{array}{l}\text { Female: } 3 \\
\text { Male: } 7\end{array}$ & $\begin{array}{l}\text { Farming: } 3 \\
\text { Business: } 2 \\
\text { Tourism: } 2 \\
\text { Education: } 3\end{array}$ \\
\hline Suburban A) & 10 & $\begin{array}{l}\text { Long-term residents: } 4 \\
\text { New residents: } 4 \\
\text { Moved out: } 2\end{array}$ & $\begin{array}{l}\text { 1920s: } 3 \\
\text { 1930s: } 1 \\
\text { 1940s: } 4 \\
\text { 1960s: } 2\end{array}$ & $\begin{array}{l}\text { Active: } 3 \\
\text { Not active: } 7\end{array}$ & $\begin{array}{l}\text { Female: } 6 \\
\text { Male: } 4\end{array}$ & $\begin{array}{l}\text { Farming: } 1 \\
\text { Business: } 3 \\
\text { Health: } 2 \\
\text { Education: } 2 \\
\text { Craftsmanship: } 1 \\
\text { Self-employed: } 1\end{array}$ \\
\hline Suburban B) & 8 & $\begin{array}{l}\text { Long-term residents: } 4 \\
\text { New residents: } 2 \\
\text { Moved out: } 2\end{array}$ & $\begin{array}{l}\text { 1920s: } 4 \\
\text { 1940s: } 2 \\
\text { 1960s: } 2\end{array}$ & $\begin{array}{l}\text { Active: } 3 \\
\text { Not active: } 5\end{array}$ & $\begin{array}{l}\text { Female: } 3 \\
\text { Male: } 5\end{array}$ & $\begin{array}{l}\text { Farming: } 3 \\
\text { Business: } 4 \\
\text { Self-employed: } 1\end{array}$ \\
\hline
\end{tabular}

restoring landscapes (Hall 2005). In a study by Hoffenberg (2001) it was shown how important historical landmarks are in the collective memory of societies. Schama (1995) showed how memory and landscape are interconnected, and how landscape perception is over-formed by cultural and national identity. Vos and Meekes (1999) as well as Marcucci (2000) tried to implement the historical perspective into the planning process.

Our own study focused on preferences regarding landscape changes in the (Swiss) Alps, a region where a growing public awareness of the need to guide landscape transformation can be observed. This public debate resulted in a multitude of National Research Programs (eg the Swiss National Research Program NRP48 and the Austrian Research Program on "Sustainable Development of Austrian Landscapes and Regions," ALR). The most recent studies on the social dimension of Alpine landscapes in Switzerland are described by Backhaus et al (2007). Landscape development preferences in other European mountains were most recently investigated by Soliva et al (2008). This study revealed that withdrawal of mountain agriculture due to economic liberalization has little public support in all the study areas across Europe. Daugstad et al (2006) report similar findings. Older studies focusing on Alpine landscape development were done by Nohl and Neumann (1987), Hunziker (1992, 1995), Hunziker and Kienast (1999), and MacDonald et al (2000).

Only a few preference studies exist from other European mountain areas (eg Ruiz and Ruiz 1989;
Strumse 1996; Gómez-Limón and Fernández 1999). Outside Europe, general landscape preference studies (see above), as well as ecologically or planning-oriented studies in mountain areas are numerous (eg Riebsame et al 1996; Paquette and Domon 2002; Platt 2004). However studies emphasizing landscape preference in mountain landscapes are hard to find. We refer to the publication by Theobald et al (1996), who reported enhanced local awareness of rapid landscape change in Colorado, and the study by Foran and Wardle (1995) in New Zealand, who found 3 distinct preference patterns in the population, ie the "technocrats," the "green," and the "forest-green"-oriented individuals. We found no studies specifically on landscape preferences in developing countries.

Despite the extensive body of literature on landscape preferences in general, there has been a lack of research focusing on group-specific perception and assessment of past and expected future landscape changes in mountains. The purpose of the presented study is to bridge these gaps and to achieve the abovementioned 2 objectives.

\section{Methods}

Achieving the 2 main objectives of our study required 2 different study designs: a) an in-depth analysis to analyze perceptions of (past) landscape changes, and b) representative surveys to study differences in perception among social groups. 
FIGURES 1A-1D The "Status quo" scenario $(1 \mathrm{~A})$ is very frequent in the Alps. It represents a well-maintained cultural landscape with some abandonment and reforestation in marginal areas. The "Intensification" scenario (1B) depends on intensive cultivation wherever possible. This scenario is rather unlikely, but high food and energy prices could favor such a scenario. The

"Restoring tradition" scenario (1C) displays the "back to the traditional cultural landscape" approach, with many traditional landscape elements. This scenario would become true if all agricultural subsidies were bound to biodiversity enhancement schemes. The "Reforestation" scenario (1D) shows a situation with vast areas of abandoned and spontaneously reforested land. This scenario is likely in many Alpine regions after drastic reduction of agricultural subsidies, resulting in abandonment of the landscape-related activities of farms and forestry enterprises. (Photos and photo editing by Andreas Lienhard)
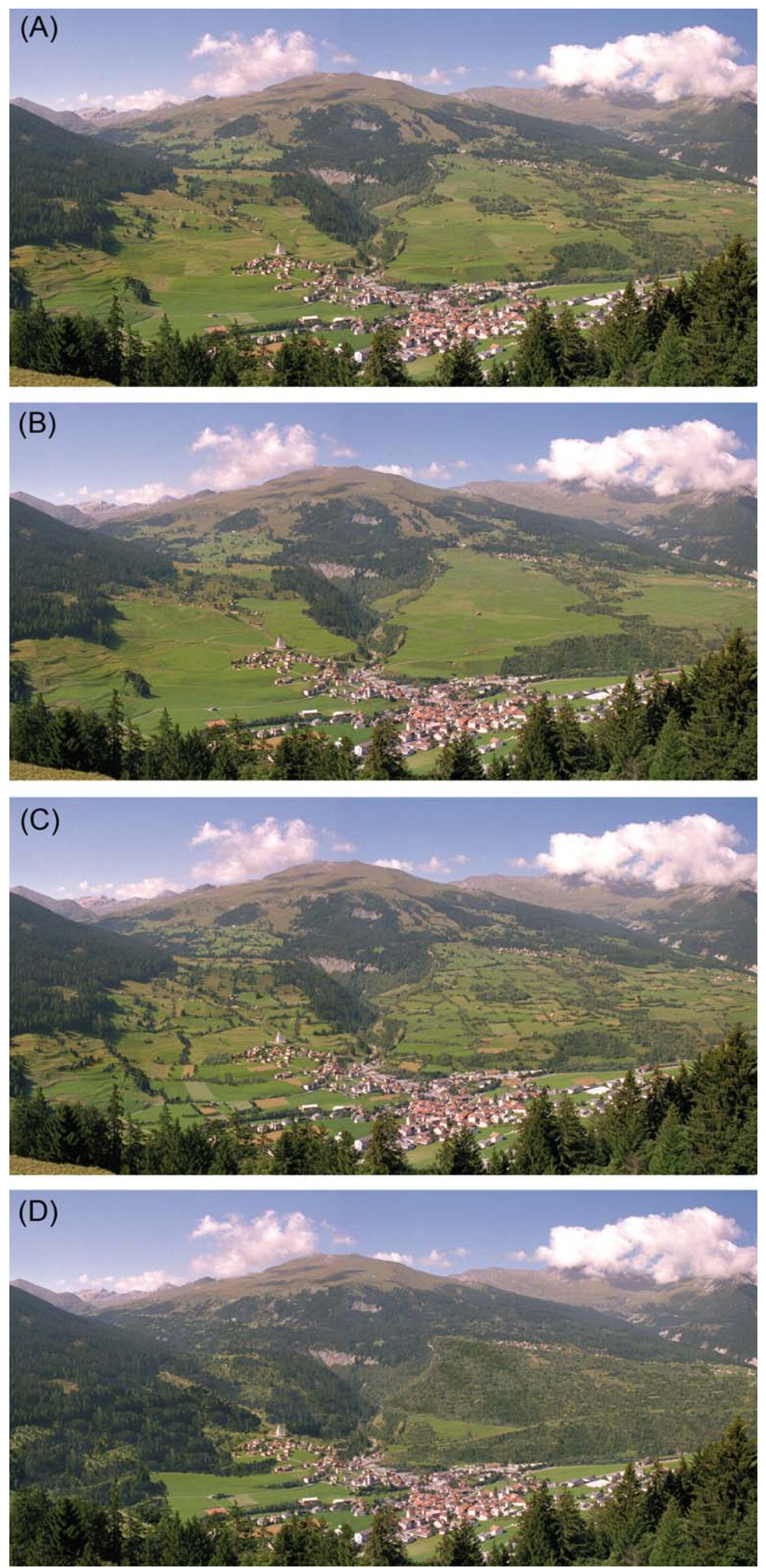

For the inductive-explorative part of our study (part a), we conducted case studies in 4 Swiss municipalities (Schneeberger et al 2007) that have experienced different transformation rates, ie:

- An agrarian village without drastic landscape changes;

- An agrarian municipality that developed into an important tourist destination;

- Two small craft and trade towns that developed into suburban cities with industrial features.

In each research area we undertook 8 to 10 in-depth problem-centered interviews (Witzel 1989) combined with walking tours through the municipality.

As for selection of the interviewees, we applied the theoretical sampling approach described by Strauss and Corbin (1996) and Hunziker (1995, 2000). The principle of this approach is to find the maximum contrast among interviewees regarding the sample-selection criteria relevant to the objective of the study. For example, the age of the respondents was selected in a way to guarantee full coverage of child, adolescent, and adult perceptions of the landscape between the 1930s and the present. Other sample selection criteria as well as corresponding interviewee descriptions are displayed in Table 1. All interviews were tape-recorded, transcribed, and analyzed according to qualitative content analysis (Mayring 2000).

The assessment of expected future landscape changes by different societal groups was analyzed in the deductive-representative part of the study (part b). We conducted a nation-wide representative postal survey that encompassed 4 sub-samples:

- Resident population in the German- and Frenchspeaking parts of Switzerland (resulting sample size $\mathrm{N}=1016$; response rate $=25 \%$ ). As the majority (about $70 \%$ ) of the Swiss public lives in urban and peri-urban areas, this sub-sample can be considered as the "urban" sample.

- Inhabitants of 2 Alpine regions, the Albula Valley and the Surses $(\mathrm{N}=75$; response rate $=15 \%)$. These 2 valleys belong to rural Alpine areas. At the same time, both valleys are highly influenced by tourism: infrastructure-oriented tourism in the Surses, natureand landscape-related tourism in the Albula Valley. Thus, this sub-sample represents the typical "average" population in the Swiss Alps living in rural areas with tourism.

- Tourists of the Albula Valley and the Surses ( $N=510$; response rate $=46 \%) ; 50 \%$ of the respondents were winter guests and $50 \%$ summer (autumn) guests. This sub-sample represents the "average" tourist in the Alps: skiers (Surses), hikers, etc. 
FIGURE 2 Example of a landscape element typical for a certain region or

- Landscape experts and decision-makers at the local, regional, and national levels $(\mathrm{N}=72$; response rate $=$ $71 \%$ ). This sample represents a selection of professionals dealing with landscape development. We assume that they are biased due to their professional perspective or role, eg local or regional politician, regional or national nature/landscape conservationist, regional or national spatial planner, cantonal or federal authorities, etc.

For the present study, assessments of landscape scenario visualizations were of key importance. The interviewees were asked to rank such visualization on a 5point scale from $1=$ 'do not like at all' to $5=$ 'like very much.' All the visualizations were based on results of preceding expert interviews and literature analyses revealing the most relevant (future) landscape changes in the (Swiss) Alps. The following scenarios were included: status quo, intensification, restoring tradition, reforestation. The visualizations of the scenarios are displayed in Figures 1A to 1C, and further described below in the Results.

All analyses of the deductive part were conducted with SPSS 11 for Mac OS X using ANOVA.

\section{Results}

\section{Assessment of past landscape change and the role of landscape meanings}

In all research areas, the interviewees noticed an increase in residential areas, ongoing expansion of the road network, growth of forested areas, and a decline of grassland areas. These major changes were well accepted in all municipalities. Hence, the adaptive capacity of the public to landscape changes is high. Transformations were perceived negatively if they were massive (eg agricultural areas to built-up areas) or if they contrasted with the collective value system of the community. For example, according to their collective value system, agrarian communities tended to assess losses or gains in meadows in terms of potential losses or gains of biomass (grass). In contrast, peri-urban communities valued meadows in terms of their recreational potential. The rate of change appeared not to be decisive for positive or negative valuation.

It became apparent that landscape elements have distinct collective meanings as well as different meanings for individuals. These meanings are driven by collective or individual value systems. Apart from the above-mentioned common landscape elements, this holds true in particular for landscape elements that are specific to a certain region or municipality. Examples include schools (Figure 2), distinct typical houses, and natural landscape elements. The results revealed that strong feelings existed regarding all kinds of "unspec-

FIGURE 3 Example of a landscape element important for an individual. (Photo by Patricia Felber Rufer)

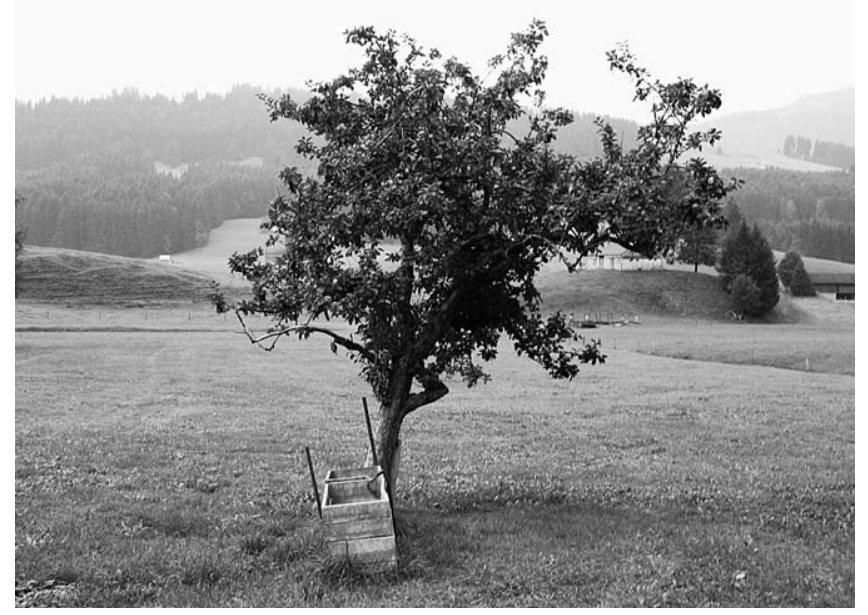

tacular" landscape features, eg a certain spot where one used to go for a walk or a tree from childhood (Figure 3). These landscape elements play a crucial role when it comes to judging landscape change, because people attach a special meaning to them and notice even slight changes.

In addition, we found landscape elements (buildings, infrastructure) for which values changed over time. These elements were considered disturbing at the time they were built but were becoming an integral part of the landscape and a symbol of the community. In one municipality, for example, the population was dissatisfied with the installation of a T-bar ski lift and especially the impact of the pylons on the scenery. However, over time, the ski lift became a landmark and symbol of the municipality's tourism potential.

Our analysis revealed that landscape elements which had a function after changes had occurred were assessed more positively than those that lost their function over time. However, some elements have very great 
FIGURE 4 Assessments of the potential future development of cultural landscapes by 3 societal groups: the general Swiss public, inhabitants of an affected region (Mid-Grisons), and tourists. Respondents assessed the visualized scenarios on a 5 -point scale $(1=$ 'do not like at all' to $5=$ 'like very much').

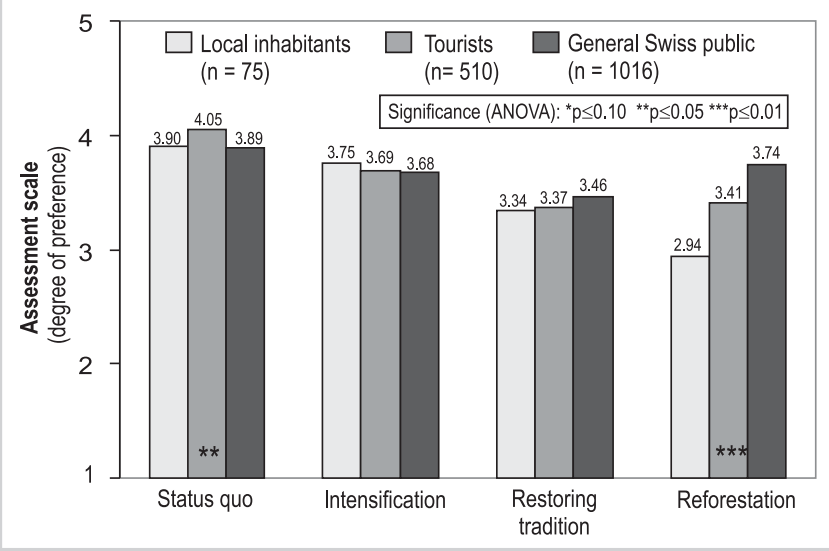

FIGURE 5 Assessments of the potential future development of cultural landscapes by experts and decision-makers on the one hand, and the general Swiss public on the other (same 5-point scale as described in Figure 4).

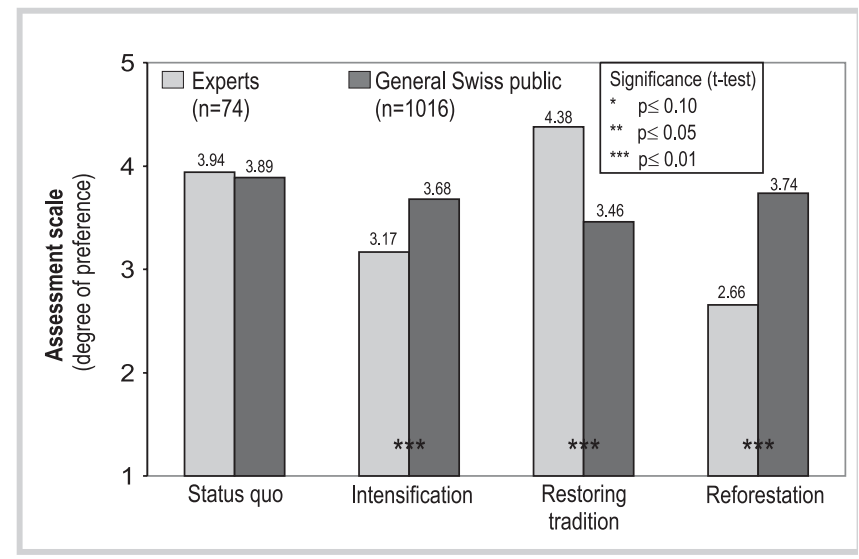

emotional significance; hence high protection costs are accepted even if the elements have lost their function (eg shacks to store peat).

\section{Assessment of future landscape change by different societal groups}

Group-specific assessments were analyzed for both rewilding and preserving scenarios. One of the main results is shown in Figure 4: the groups under consideration assessed almost all scenarios positively. The differences between values attributed to the 4 scenarios by the 3 groups are rather small-though they are significant in paired t-tests. In particular, the general Swiss public made no great differentiation in their assessment of the 4 scenarios. Even the most-discussed and often criticized scenario of abandonment and reforestation had a relatively high rating.

Generally, the differences between groups are small. However, as the ANOVA (F-test) revealed, the reforestation scenario had a significant between-group difference: local inhabitants rated it significantly lower than the general Swiss public. Tourists' assessments hovered between the two extremes. Between-group differences exist, although they are less impressive, even for the status quo scenario: the tourists rated this scenario higher than the local inhabitants of the Alpine study region and the general Swiss public. There were further significant group differences, again mainly regarding the reforestation scenario: eg members of environmental organizations gave this scenario a higher rating than non-members, females and people living in urban areas assessed reforestation more positively than males and those living in rural areas. There was, by contrast, no significant effect owing to age, education, and language.

Figure 5 shows that experts and decision-makers have a clear preference for a return to the traditional cultural landscape. Their ratings for this scenario were significantly higher than the ratings of the general Swiss public. By contrast, they rated both the intensification scenario and the reforestation scenario significantly lower than the Swiss public. Regarding the reforestation scenario, the difference is very large. The only scenario where both experts and the Swiss public agree is that of the status quo.

\section{Discussion}

The results of the inductive part reveal that all 4 municipalities under observation had undergone landscape changes in a manner that almost all inhabitants had been able to adapt to. Additionally, our findings confirm that landscape change as such is not disturbing-a conclusion also drawn by Brown et al (2003). We found that people need to be able to leave traces on the landscape. This result corroborates the findings of Twigger-Ross and Uzzell (1996) and Buchecker (2005), who stress the relevance of changes in the formation of place identity and attachment. However, our results contrast with the results of the study by Theobald et al (1996) in the Colorado Mountains, who found an increasing awareness of rapid landscape changes. This difference is likely to be culturally driven and might stem from a different view of wilderness and nature conservation outside settlements as elaborated by Hall (2005). Additionally, it is possible that the contrasting findings of Theobald et al (1996) and the most recent literature are a result of value changes during the last 12 years.

Some landscape elements are characterized by changing valuation through time: some are considered as disturbing at the beginning, but later they become a symbol of the community. Hay (1998) found the same trend and concluded that time is the most important 
factor in the genesis of place attachment. Nevertheless, there is a certain demand to retain elements from the past, as already mentioned by Hoffenberg (2001), who stressed the relevance of historical elements for the valuation of a landscape. In addition, our finding that some elements have an especially high emotional benefit and thus lead to the acceptance of high protection costs corroborates the findings of Holloway and Hubbard (2001).

The results of the deductive part show that the general Swiss public assesses all scenarios of cultural landscape change positively. This is especially true for reconstruction scenarios aiming at restoring the traditional landscape, as well as for spontaneous reforestation scenarios. This result is rather surprising because previous studies have found that extensive and homogenous spontaneous reforestation tends to be viewed negatively (Volk 1985; Hunziker 1995; Tahvanainen et al 1996; Hunziker and Kienast 1999). However, as other recent studies in Switzerland and the Netherlands have also found rather positive attitudes towards rewilding (eg Bauer 2005; Van den Berg and Koole 2006), these findings could be an expression of a general change in valuations of nature, which have an important influence on landscape preferences (Kaltenborn and Bjerke 2002). At the same time, the results presented by Soliva et al (2008) suggest that most stakeholders in Europe's mountain regions do not favor a complete withdrawal of agriculture as a result of liberalization. Soliva's study is primarily based on stakeholders residing in the mountain region or belonging to related interest and expert groups. Thus it corroborates the differing preferences among mountain dwellers and (outside) experts found in the present study.

Our results revealed considerable and significant differences between social groups, in particular between the general Swiss public and inhabitants of the study regions, primarily regarding the reforestation scenario. This result is not surprising and is the expression of a long-lasting societal debate about the future of Alpine landscapes. Rewilding is pushed by various NGOs (eg Arnold 2005) and expert teams (eg Diener et al 2006). This explains why the ratings of the members of these organizations are considerably different from those directly affected. The latter fear a loss of cultural heritage and income opportunities (Kianicka et al 2006). This result has also been found by several other authors (eg Van den Berg and Koole 2006), in particular in other European mountains (eg Strumse 1996; Gómez-Limón and Fernández 1999). Surprisingly, there were no differences due to age, education, and culture (ie language regions) in our study. This is in contrast to several published studies exhibiting a fairly large influence of these variables (Yu 1995; Strumse 1996; Van den Berg et al 1998; Stamps 1999;
Van den Berg and Koole 2006). It seems that the recent societal debate in Switzerland has determined the main positions independently of socio-demographic characteristics.

However, one traditionally relevant driver of landscape preferences was confirmed, ie the type of profession. This confirms reports by Dearden (1984), Strumse (1996) and Van den Berg et al (1998), as well as findings from mountain areas outside Europe, eg in New Zealand (Foran and Wardle 1995). These authors found that landscape experts and decision-makers assess landscape developments consistently differently than lay people. In our case, the experts rated return to the traditional cultural landscape much higher, and both reforestation and intensification much lower than the general Swiss public. One might recognize in the experts' perspective the long-lasting effect of the MAB Program, which explicitly promoted maintenance of the traditional cultural landscape in the Alps (Messerli 1989).

Before drawing final conclusions, we must note the adequacy of the methods and comment on the subsequent limitations of the results. Combining narratives with walking tours and in-situ assessment of past landscape changes was very successful. The walking trips stimulated interviewees' memories. Additionally, we noticed that memories are rather sensitive to differences and meanings but rather insensitive to rates of change. Therefore, our result that the transformation rate does not play an important role must be interpreted with care.

The measurement of landscape preferences by use of questionnaires and visualizations, as well as the statistical comparisons between the different samples, worked in a satisfactory way and yielded clear and consistent results. The response rates were rather low and differed considerably between the sub-samples, carrying the risk of distorting the sample. However, analysis of the sample of the resident population (Swiss public and inhabitants of the study area) revealed that it was not biased, as the socioeconomic properties of the sample did not differ from the values of the sampling universe.

\section{Conclusions}

A crucial result of our investigations is that landscape change per se is not disturbing. People prefer dynamic landscapes where they can leave and recognize traces of their own. Thus, landscape planners need to be aware of the fact that people are very adaptive to landscape change. At the same time, historical aspects of landscapes are important factors in the formation and stabilization of identity. Thus, landscape development needs to be guided very carefully and consciously in order to 
find the balance between the two opposing expectations regarding landscapes.

Management and planning agencies should take into account the considerable differences between expert view(s) and the view(s) of the general public. If major decisions are based on expert views only, they may fail to meet public needs and risk causing resistance. Thus, public involvement strategies are necessary.

The differences between the assessments of people living inside and outside the Alpine region are often over-estimated. Our results show a large consensus in several important landscape scenarios. Landscape planners and politicians can rely on this basic consensus.
Nevertheless, regarding the most recent and relevant development, "land abandonment and reforestation," there is a considerable difference between people living inside and outside the Alps. For this reason landscape management agencies-often guided by institutions outside the Alpine area-must include the views of people living in the Alps. However, the outside view is important since it includes the views of (a) the tourists representing the market for this landscape, and (b) the people who support landscape development in the Alps with their taxes. And last but not least, Alpine landscapes are part of the world's cultural and natural heritage.

\section{ACKNOWLEDGMENTS}

The studies presented in this article were supported by funding from the Swiss National Science Foundation (SNSF) within the framework of NRP 48, "Landscapes and Habitats of the Alps." Further financial support was provided by the Swiss Federal Agency for the Environment and the Canton of Grisons. We thank two anonymous reviewers, the guest editor, and the MRD editorial team for valuable comments that helped to improve the quality of the manuscript.

\section{AUTHORS}

Marcel Hunziker, Katrin Gehring, Matthias Buchecker, Nicole Bauer, Felix Kienast

Swiss Federal Research Institute WSL, 8903 Birmensdorf, Switzerland. marcel.hunziker@wsl.ch; matthias.buchecker@wsl.ch;

nicole.bauer@wsl.ch; felix.kienast@wsl.ch

Patricia Felber

Institute of Geography, University of Bern, Hallerstrasse 12, 3012 Berne, Switzerland.

felber@giub.unibe.ch

\section{REFERENCES}

Aoki Y. 1999. Trends in the study of the psychological evaluation of land scape [Review]. Landscape Research 24:85-94.

Arnold M. 2005. Keine Angst vor Wildnis. Pro Natura Magazin 2005(1):12-13. Backhaus N, Reichler C, Stremlow M. 2007. Alpenlandschaften-Von der Vorstellung zur Handlung. Thematische Synthese zum Forschungsschwerpunkt I "Prozesse der Wahrnehmung." Zurich, Switzerland: vdf.

Bätzing W. 1991. Die Alpen. Entstehung und Gefährdung einer europäischen Kulturlandschaft. Munich, Germany: C.H. Beck.

Bauer N. 2005. Für und wider Wildnis. Soziale Dimensionen einer aktuellen gesellschaftlichen Debatte. Bristol-Schriftenreihe 5. Berne, Switzerland: Haupt Bourassa SC. 1991. The Aesthetics of Landscape. London, United Kingdom: Belhaven Press.

Brown B, Perkins DD, Brown G. 2003. Place attachment in a revitalizing neighborhood: Individual and block levels of analysis. Journal of Environmental Psychology 23:259-271.

Buchecker M. 2005. Public place as a resource of social interaction. In: Turner P, Davenport E, editors. Spaces, Spatiality and Technology. Dordrecht, The Netherlands: Springer, pp 79-96.

Daugstad K, Ronningen K, Skar B. 2006. Agriculture as an upholder of cultural heritage? Conceptualizations and value judgements-a Norwegian perspective in an international context. Journal of Rural Studies 22:67-81. Dearden P. 1984. Factors influencing landscape preferences: An empirical investigation. Landscape Planning 11:293-306.

Diener R, Herzog J, Meili M, de Meuron P, Schmid C. 2006. Die Schweiz. Ein städtebauliches Portrait. Basel: Birkhäuser Verlag für Architektur. Foran B, Wardle K. 1995. Transitions in land-use and the problems of planning: A case-study from the mountainlands of New Zealand. Journal of Environmental Management 43:97-127.

Gómez-Limón J, Fernández JVD. 1999. Changes in use and landscape pref erences on the agricultural-livestock landscapes of the central Iberian Peninsula (Madrid, Spain). Landscape and Urban Planning 44:165-175. Hall M. 2005. Earth Repair: A Transatlantic History of Environmental Restoration. Charlottesville, VA: University of Virginia Press.
Hay R. 1998. Sense of place in development context. Journal of Environmental Psychology 18:5-29.

Hoffenberg PH. 2001. Landscape, memory and the Australian war experience, 1915-18. Journal of Contemporary History 36:111-131.

Holloway L, Hubbard P. 2001. People and Place. The Extraordinary Geographies of Everyday Life. New York: Prentice Hall.

Hunziker M. 1992. Tourismusbedingte Landschaftsveränderungen im Urteil der Touristen. Geographica Helvetica 1992(4):143-149.

Hunziker M. 1995. The spontaneous reafforestation in abandoned agricultural lands: Perception and aesthetic assessment by locals and tourists. Landscape and Urban Planning 31:399-410.

Hunziker M. 2000. Einstellungen der Bevölkerung zu möglichen Landschaftsentwicklungen in den Alpen. Birmensdorf, Switzerland: Eidgenössische Forschungsanstalt WSL.

Hunziker M, Buchecker M, Hartig T. 2007. Space and Place-two aspects of the human-landscape relationship. In: Kienast F, Ghosh S, Wildi O, editors. A Changing World-Challenges for Landscape Research. Landscape Series. Dordrecht, The Netherlands: Springer, pp 47-62.

Hunziker M, Kienast F. 1999. Impacts of changing agricultural activities on scenic beauty: A prototype of an automated rapid assessment technique. Landscape Ecology 14:161-176.

Kaltenborn BP, Bjerke T. 2002. Association between environmental value orientations and landscape preferences. Landscape and Urban Planning 59:1-11.

Kianicka S, Buchecker M, Hunziker M, Müller-Böker U. 2006. Locals' and tourists' sense of place: A case study in a Swiss Alpine village. Mountain Research and Development 26:55-63.

Kienast F, Ghosh S, Wildi 0, editors. 2007. A Changing World: Challenges for Landscape Research. Landscape Series. Dordrecht, The Netherlands: Springer.

Lehmann B, Steiger U, Weber M. 2007. Landschaften und Lebensräume der Alpen. Zwischen Wertschöpfung und Wertschätzung. Reflexionen zum Abschluss des Nationalen Forschungsprogramms 48. Zurich, Switzerland: vdf. 
MacDonald D, Crabtree JR, Wiesinger G, Dax T, Stamou N, Fleury P, Lazpita JG, Gibon A. 2000. Agricultural abandonment in mountain areas of Europe: Environmental consequences and policy response. Journal of Environmental Management 59:47-69.

Marcucci DJ. 2000. Landscape history as a planning tool. Landscape and Urban Planning 49:67-81.

Mayring P. 2000. Qualitative Inhaltsanalyse. Weinheim, Germany: Deutscher Studienverlag.

Messerli P. 1989. Mensch und Natur im alpinen Lebensraum. Risiken, Chan cen, Perspektiven. Berne, Switzerland: Haupt.

NohI W, Neumann KD. 1987. Ästhetische Wahrnehmung der Landschaft und Freizeitmotivation, oder wie beurteilen Wintersportler ihr Skigebiet im sommerlichen Zustand? Landschaft und Stadt 19:156-164.

Paquette S, Domon G. 2001. Trends in rural landscape development and sociodemographic recomposition in southern Quebec (Canada). Landscape and Urban Planning 55:215-238.

Platt RV. 2004. Global and local analysis of fragmentation in a mountain region of Colorado. Agriculture Ecosystems and Environment 101:207-218. Real E, Arce C, Sabucedo JM. 2000. Classification of landscapes using quantitative and categorical data and prediction of their scenic beauty in North-Western Spain. Journal of Environmental Psychology 20:355-373. Riebsame WE, Gosnell H, Theobald DM. 1996. Land use and landscape change in the Colorado Mountains. 1. Theory, scale, and pattern. Mountain Research and Development 16:395-405.

Ruiz M, Ruiz JP. 1989. Landscape perception and technological change in the Central Mountains of Spain. Landscape and Urban Planning 18:1-15.

Russell EWB. 1997. People and Land Through Time. Linking Ecology and History. New Haven, CT: Yale University Press.

Schama S. 1995. Landscape and Memory. London, United Kingdom: Harper Collins.

Schneeberger N, Bürgi M, Kienast F. 2007. Rates of landscape change at the northern fringe of the Swiss Alps: Historical and recent tendencies. Landscape and Urban Planning 80:127-136.

Soliva R, Ronningen K, Bella I, Bezak P, Cooper T, Flo BE, Marty $P$

Potter C. 2008. Envisioning upland futures: Stakeholder responses to scenarios for Europe's mountain landscapes. Journal of Rural Studies 24(1):56-71.
Stamps AE. 1999. Demographic effects in environmental aesthetics: A meta analysis. Journal of Planning Literature 14:125-175.

Strauss A, Corbin J. 1996. Grounded Theory: Grundlagen qualitativer Sozialforschung. Weinheim, Germany: Beltz, Psychologie Verlags Union.

Strumse E. 1996. Demographic differences in the visual preferences for agrarian landscapes in western Norway. Journal of Environmental Psychology 16:17-31.

Tahvanainen L, Tyrväinen L, Nousiainen I, Benson RE, McCool SF, Schlieter

JA. 1996. Effect of afforestation on the scenic value of rural landscape: Attaining visual quality objectives in timber harvest areas. Landscape architects' evaluation. Scandinavian Journal of Forest Research 11:397-405.

Theobald DM, Gosnell H, Riebsame WE. 1996. Land use and landscape change in the Colorado Mountains: A case study of the East River Valley. Mountain Research and Development 16:407-418.

Twigger-Ross CL, Uzzell DL. 1996. Place and identity processes. Journal of Environmental Psychology 16:205-220.

Van den Berg AE, Koole SL. 2006. New wilderness in the Netherlands: An investigation of visual preferences for nature development landscapes. Landscape and Urban Planning 78:362-372.

Van den Berg AE, VIek CA, Coeterier JF. 1998. Group differences in the aesthetic evaluation of nature development plans: A multilevel approach. Journal of Environmental Psychology 18:141-157.

Volk H. 1985. Wieviel Wald gehört zur Erholungslandschaft? Befragungsergebnisse für das Naturschutzgebiet Feldberg im Schwarzwald. Natur und Landschaft 60:500-504.

Vos W, Meekes H. 1999. Trends in European cultural landscape development: Perspectives for a sustainable future. Landscape and Urban Planning 46:3-14.

Witzel A. 1989. Das problemzentrierte Interview. In: Jüttemann G, editor Qualitative Forschung in der Psychologie. Grundfragen, Verfahrensweisen, Anwendungsfelder. Heidelberg, Germany: Asanger, pp 227-256.

Yu K. 1995. Cultural variations in landscape preferences: Comparisons among Chinese sub-groups and Western design experts. Landscape and Urban Planning 32:107-126.

Zube EH. 1984. Themes in landscape assessment theory. Landscape Journal 3:104-109. 